\title{
COMPARATIVE ASSESSMENT OF COMPETENCE LEVEL OF TRANSPORT SYSTEM EXPERTS
}

\author{
Grigore Ambrosi*, ORCID ID: 0000-0001-7232-2998 \\ Technical University of Moldova, 168, Ștefan cel Mare și Sfânt Bd., Chisinau, Republic of Moldova \\ *Corresponding author: Grigore Ambrosi, grigore.ambrosi@tran.utm.md
}

Received: 10. 18. 2021

Accepted: 12. 04. 2021

\begin{abstract}
The paper deals with the comparative assessment of competence level of transport system experts. The high level of competence of the experts is the premise to ensure the quality of the expertise of the systems insufficiently formalized from a mathematical point of view and characterized with a high degree of uncertainty. Six factors for assessing the competence of transport system experts were summarized. The values of the priority vector of the competence factors were established with the application of the Saaty algorithm and scale in nine points by the method of comparisons in pairs. The value of the concordance ratio of the experts' opinion for the prioritization matrix was calculated. The comparative competence coefficient of the experts in transport systems was calculated and the hierarchy of experts was established according to the value of the nominal coefficient.
\end{abstract}

Keywords: transport, expert, factor, competence, level, calculation, hierarchy.

Rezumat. Lucrarea abordează problema evaluării comparative a nivelului de competență al experților în sisteme de transport. Nivelul ridicat de competență al experților este premisa asigurării calității expertizei sistemelor insuficient formalizate din punct de vedere matematic și caracterizate cu un grad ridicat de incertitudine. Au fost sintezați șase factori pentru evaluarea competenței experților în sisteme de transport. Valorile vectorului prioritar al factorilor de competență au fost stabilite cu aplicarea algoritmului Saaty și a scării în nouă puncte prin metoda comparațiilor în perechi. S-a calculat valoarea raportului de concordanță al opiniei experților pentru matricea de prioritizare. A fost calculat coeficientul comparariv de competență al experților în sistemele de transport și stabilită ierarhia experților în funcție de valoarea coeficientului nominalizat.

Keywords: transport, expert, factor, competență, nivel, calcul, ierarhie.

\section{Introduction}

Developed and applied primarily for the optimization of forecasts in the field of science and technology, modern methods of expertise are finding an increasingly common application in the study of various economic and production systems.

The objective of the nominated methods is to combine the opinions of highly qualified experts to establish the optimal ways to develop the analyzed systems. 
Expert research are of distinct significance and are usually used to validate operational logic and simulation results. This type of research methods is of major interest for the study of insufficiently formalized systems in mathematical terms, affected by the high degree of uncertainty and the contradictory action of external environmental factors [1], [2].

Transport systems are defined as the totality of elements (infrastructure, means of transport, operators, traffic management systems, etc.), interacting and integrated into the geographical space and the economic environment through multiple interdependent relationships. In order to adopt the most reasoned and crucial decisions regarding the development of transport systems, it is necessary to apply various informal methods, in particular modern methods of expertise.

In cases characterized by a high level of uncertainty, specific to modern transport systems, evaluations based on the experience, competence, elaborations, concepts, ideas, opinions and hypotheses of highly qualified specialists in the respective field can be used as realistic solutions [3 - 6]. Qualitative selection of experts in transport systems involves the use of the following main criteria: competence, objectivity, creativity, non-conformism, constructive thinking, teamwork, self-criticism, availability and professional interest [7 - 9].

Sometimes decision-makers in transport systems invite various specialists as experts in the field, whose competence is not analyzed compared to the level of other experts, included in the research group [4], [6].

The competence of an expert reflects the person's level of qualification in a particular field, which can be assessed as a result of the relevant analysis of his activity, the level and extent of knowledge of scientific and technological achievements, the depth of understanding the essence and root causes of problems, of the development perspectives of the researched sector [1], [2], [7].

The process of selecting the optimal number of competent experts for the synthesis of statistically stable solutions for transport systems is one of decisive importance.

Increasing the number of competent experts in the research group minimizes the likelihood of making wrong decisions and improves the quality of the evaluation [1], [8]. Improving the reliability of expert evaluations by attracting the most competent experts is the most important task.

From a scientific point of view, the issue of assessing the competence of experts is not considered to be definitively resolved [1], [7].

\section{Comparative assessment of the level of competence of transport system experts}

In accordance with the generally accepted methodology, the selection of experts with the highest levels of competence from a group is made in the following sequence: 1) establishing the list of competence factors for the category analyzed by experts; 2) assessment of the competence of experts for the list established by factors based on objective criteria; 3) determining the priority hierarchy of competence factors; 4) evaluation of the comparative level of competence of the experts considering the priority of the competence factors; 5) choosing the experts with maximum values of the comparative coefficient of competence [7], [8].

The competence of experts in transport systems is proposed to be assessed with the following main factors: 1) the level of professional qualification; 2) practical experience in the field; 3) managerial experience corresponding to the level of expertise issues; 4) the number of scientific monographs in the field; 5) the number of scientific publications in the 
field in journals with impact factor; 6) the number of participations in national and international projects in the field. The options for the answers for each proposed competence factor and the corresponding values of the weighting coefficient are presented in Table 1.

The methodology for comparative assessing of the level of competence of transport system experts based on the proposed competence factors is set out below. For each expert $i$, included in the group of specialists in transport systems, the individual score corresponding to each competence factor $j$ is calculated with the following relation:

$$
\sum X_{i}=\sum_{j=1}^{n} a_{i j}
$$

For each competence factor $j$ the summary score of all experts in the group is calculated, as well as the total score of all factors according to the formula:

$$
\sum F_{j}=\sum_{i=1}^{m} a_{i j}
$$

The value of the weighting coefficient $C_{W}$ of each expert in the group for all competence factors is determined as follows:

$$
C_{W}=\frac{\sum_{i=1}^{m} \sum_{j=1}^{n} a_{i j}}{\sum_{j=1}^{n} a_{i j}}
$$

\begin{tabular}{|c|c|c|c|}
\hline Competency factor & $C_{W}$ & Competency factor & $C_{W}$ \\
\hline 1.Level of professional qualification & \multicolumn{3}{|c|}{ 4. The number of scientific monographs } \\
\hline - Undergraduate studies & 0,15 & $\bullet 0$ & 0,00 \\
\hline - Masters & 0,25 & - 1 & 0,20 \\
\hline \multirow[t]{3}{*}{ - Doctoral studies } & 0,60 & - 2 & 0,25 \\
\hline & & - 3 & 0,30 \\
\hline & & - 4 and more & 0,35 \\
\hline 2. Practical experience in the field & \multicolumn{3}{|c|}{$\begin{array}{l}\text { 5. The number of scientific publications in the } \\
\text { field in journals with impact factor }\end{array}$} \\
\hline - Up to 6 years & 0,10 & $\bullet 0$ & 0,00 \\
\hline - From 6 to 10 years & 0,15 & - 1-5 & 0,20 \\
\hline - From 11 to 15 years & 0,20 & - 6-15 & 0,25 \\
\hline - From 16 to 20 years & 0,25 & - $16-25$ & 0,30 \\
\hline - Over 20 years & 0,30 & - Over 25 & 0,35 \\
\hline \multicolumn{2}{|l|}{ 3.Managerial experience in the field } & \multicolumn{2}{|c|}{$\begin{array}{l}\text { 6. The number of participations in national } \\
\text { and international projects }\end{array}$} \\
\hline - Up to 6 years & 0,10 & $\bullet 0$ & 0,00 \\
\hline - From 6 to 10 years & 0,15 & - 1-2 & 0,20 \\
\hline - From 11 to 15 years & 0,20 & - 3-4 & 0,25 \\
\hline - From 16 to 20 years & 0,25 & - 4-6 & 0,30 \\
\hline - Over 20 years & 0,30 & - Over 6 & 0,35 \\
\hline
\end{tabular}

Table 1

Values of the weighting coefficient $C_{W}$ of the competence factors

The results of the calculations based on relations (1)-(3) are shown in Table 2. 
Calculation of expert weighting coefficients $C_{W}$

\begin{tabular}{|c|c|c|c|c|c|c|c|c|}
\hline \multirow{2}{*}{$\begin{array}{l}\text { Expert } \\
\text { number }\end{array}$} & \multicolumn{6}{|c|}{ Competency factor number } & \multirow{2}{*}{$\sum X_{i}$} & \multirow{2}{*}{$C_{W}$} \\
\hline & 1 & 2 & 3 & 4 & 5 & 6 & & \\
\hline 1 & 0,60 & 0,30 & 0,25 & 0,30 & 0,35 & 0,35 & 2,15 & 0,1886 \\
\hline 2 & 0,60 & 0,25 & 0,20 & 0,25 & 0,30 & 0,30 & 1,90 & 0,1667 \\
\hline 3 & 0,60 & 0,20 & 0,15 & 0,20 & 0,25 & 0,25 & 1,65 & 0,1447 \\
\hline 4 & 0,25 & 0,30 & 0,25 & 0,00 & 0,20 & 0,20 & 1,20 & 0,1053 \\
\hline 5 & 0,25 & 0,25 & 0,20 & 0,00 & 0,20 & 0,20 & 1,10 & 0,0965 \\
\hline 6 & 0,25 & 0,20 & 0,15 & 0,00 & 0,00 & 0,00 & 0,60 & 0,0526 \\
\hline 7 & 0,15 & 0,30 & 0,30 & 0,00 & 0,00 & 0,20 & 0,95 & 0,0833 \\
\hline 8 & 0,15 & 0,25 & 0,25 & 0,00 & 0,00 & 0,20 & 0,85 & 0,0746 \\
\hline 9 & 0,15 & 0,20 & 0,20 & 0,00 & 0,00 & 0,00 & 0,55 & 0,0482 \\
\hline 10 & 0,15 & 0,15 & 0,15 & 0,00 & 0,00 & 0,00 & 0,45 & 0,0395 \\
\hline$\sum F_{j}$ & 3,15 & 2,40 & 2,10 & 0,75 & 1,30 & 1,70 & 11,40 & 1,0000 \\
\hline
\end{tabular}

In order to increase the accuracy of the determination of the comparative level of competence of each expert, the values of the weighting coefficients in Table 2 are recalculated, using for this purpose the relation:

$$
b_{i j}=\frac{a_{i j}}{\sum F_{J}}=\frac{a_{i j}}{\sum_{i=1}^{m} a_{i j}}
$$

The results of the calculations based on relation (4) are shown in Table 3.

Table 3

Calculation of expert weighting coefficients $C_{W}$

\begin{tabular}{|c|c|c|c|c|c|c|c|c|}
\hline \multirow{2}{*}{$\begin{array}{l}\text { Expert } \\
\text { number }\end{array}$} & \multicolumn{6}{|c|}{ Competency factor number } & \multirow{2}{*}{$\sum X_{i}$} & \multirow{2}{*}{$C_{w}$} \\
\hline & 1 & 2 & 3 & 4 & 5 & 6 & & \\
\hline 1 & 0,1905 & 0,1250 & 0,1190 & 0,4000 & 0,2692 & 0,2059 & 1,3096 & 0,2183 \\
\hline 2 & 0,1905 & 0,1042 & 0,0952 & 0,3333 & 0,2308 & 0,1765 & 1,1305 & 0,1884 \\
\hline 3 & 0,1905 & 0,0833 & 0,0714 & 0,2667 & 0,1923 & 0,1471 & 0,9513 & 0,1585 \\
\hline 4 & 0,0794 & 0,1250 & 0,1190 & 0,0000 & 0,1538 & 0,1176 & 0,5949 & 0,0992 \\
\hline 5 & 0,0794 & 0,1042 & 0,0952 & 0,0000 & 0,1538 & 0,1176 & 0,5503 & 0,0917 \\
\hline 6 & 0,0794 & 0,0833 & 0,0714 & 0,0000 & 0,0000 & 0,0000 & 0,2341 & 0,0390 \\
\hline 7 & 0,0476 & 0,1250 & 0,1429 & 0,0000 & 0,0000 & 0,1176 & 0,4331 & 0,0722 \\
\hline 8 & 0,0476 & 0,1042 & 0,1190 & 0,0000 & 0,0000 & 0,1176 & 0,3885 & 0,0647 \\
\hline 9 & 0,0476 & 0,0833 & 0,0952 & 0,0000 & 0,0000 & 0,0000 & 0,2262 & 0,0377 \\
\hline 10 & 0,0476 & 0,0625 & 0,0714 & 0,0000 & 0,0000 & 0,0000 & 0,1815 & 0,0303 \\
\hline$\sum F_{j}$ & 1,0000 & 1,0000 & 1,0000 & 1,0000 & 1,0000 & 1,0000 & 6,0000 & 1,0000 \\
\hline
\end{tabular}

To establish the values of the priority vector of the competence factors, the nine-point Saaty algorithm and scale and the pairwise comparison method are applied [10].

The prioritization matrix, presented in Table 4, reflects the integrated opinion of the group of experts in transport systems. 
Table 4

Matrix of pair comparisons of factors (Prioritization matrix)

\begin{tabular}{ccccccccc}
\hline \multirow{2}{*}{$F_{j}$} & \multicolumn{9}{c}{$F_{i}$} & & & $\begin{array}{c}\text { Geometric } \\
\text { mean }\end{array}$ & $\begin{array}{c}\text { Priority } \\
\text { vector } V_{p}\end{array}$ \\
\cline { 2 - 8 } & $F_{1}$ & $F_{2}$ & $F_{3}$ & $F_{4}$ & $F_{5}$ & $F_{6}$ & 0,89089 & 0,11828 \\
\hline$F_{1}$ & 1,000 & 5,000 & 2,000 & 0,200 & 0,500 & 0,500 & 0,890 \\
\hline$F_{2}$ & 0,200 & 1,000 & 0,500 & 0,200 & 0,333 & 0,500 & 0,38643 & 0,05130 \\
\hline$F_{3}$ & 0,500 & 2,000 & 1,000 & 0,200 & 0,500 & 1,000 & 0,68129 & 0,09045 \\
\hline$F_{4}$ & 5,000 & 5,000 & 5,000 & 1,000 & 3,000 & 3,000 & 3,22496 & 0,42817 \\
\hline$F_{5}$ & 2,000 & 3,000 & 2,000 & 0,333 & 1,000 & 2,000 & 1,41397 & 0,18773 \\
\hline$F_{6}$ & 2,000 & 2,000 & 1,000 & 0,333 & 0,500 & 1,000 & 0,93449 & 0,12407 \\
\hline$\Sigma F_{j}$ & 10,70 & 18,00 & 11,50 & 2,266 & 5,833 & 8,000 & 7,53203 & 1,00000 \\
\hline
\end{tabular}

As the opinions of the experts in the selected group sometimes differ significantly, it is necessary to establish the specific level of concordance and the causes of the differentiation of the opinions of the specialists [1], [7], [8].

If the pair comparison method is applied, it becomes possible to assess the concordance of the experts' opinions, the concordance index for the given priority factor matrix being calculated with the following relation:

$$
I_{C}=\frac{\left(L_{\max }-N\right)}{(N-1)}=\frac{(6,286993-6)}{(6-1)}=\frac{0,286993}{5}=0,0573986
$$

where: $N$ is the number of competence factors, 6 .

The maximum eigenvalue of the competence factor prioritization matrix is determined by the formula:

$$
\begin{aligned}
& L_{\max }=\sum_{i=1}^{n} F_{j i} \cdot V_{P i}=(10,7 \cdot 0,118)+(18,0 \cdot 0,051)+(11,5 \cdot 0,090)+ \\
& +(2,266 \cdot 0,428)+(5,833 \cdot 0,187)+(7,532 \cdot 0,124)=6,286993
\end{aligned}
$$

The concordance ratio is determined by the relation:

$$
R_{C}=\frac{I_{C}}{C_{R}}=\frac{0,0573986}{1,24}=0,046289
$$

where: $C_{R}$ is the random consistency coefficient, equal to 1,24 for $N=6$ [7], [9].

As the $R_{c}$ ratio does not exceed the limit value $(0,2)$, clarification of expert evaluations is not necessary [11], [12].

The most important competence factors according to the prioritization matrix are the number of scientific monographs in the field and, respectively, of scientific publications in journals with impact factor.

The final value of the competence coefficient $C_{c}$ of each expert in the group sums the product between the values of the particular weighting coefficients $C_{W_{j}}$ of each expert (Table 3 ) and the $V_{p_{j}}$ values of the priority vector of the respective competence factors (last column of Table 4). 
Table 5

Comparative coefficient of competence of transport system experts

\begin{tabular}{|c|c|c|c|c|c|c|c|c|}
\hline \multirow{2}{*}{$\begin{array}{l}\text { Expert } \\
\text { number }\end{array}$} & \multicolumn{6}{|c|}{ Competency factor number } & \multirow{2}{*}{$\sum X_{i}$} & \multirow{2}{*}{$C_{c}$} \\
\hline & 1 & 2 & 3 & 4 & 5 & 6 & & \\
\hline 1 & 0,0225 & 0,0064 & 0,0107 & 0,1712 & 0,0505 & 0,0255 & 0,28706 & 0,28706 \\
\hline 2 & 0,0225 & 0,0053 & 0,0086 & 0,1427 & 0,0433 & 0,0218 & 0,24443 & 0,24443 \\
\hline 3 & 0,0225 & 0,0042 & 0,0064 & 0,1141 & 0,0361 & 0,0182 & 0,20179 & 0,20179 \\
\hline 4 & 0,0093 & 0,0064 & 0,0107 & 0,0000 & 0,0288 & 0,0146 & 0,07005 & 0,07005 \\
\hline 5 & 0,0093 & 0,0053 & 0,0086 & 0,0000 & 0,0288 & 0,0146 & 0,06682 & 0,06682 \\
\hline 6 & 0,0093 & 0,0042 & 0,0064 & 0,0000 & 0,0000 & 0,0000 & 0,02012 & 0,02012 \\
\hline 7 & 0,0056 & 0,0064 & 0,0129 & 0,0000 & 0,0000 & 0,0146 & 0,03956 & 0,03956 \\
\hline 8 & 0,0056 & 0,0053 & 0,0107 & 0,0000 & 0,0000 & 0,0146 & 0,03634 & 0,03634 \\
\hline 9 & 0,0056 & 0,0042 & 0,0086 & 0,0000 & 0,0000 & 0,0000 & 0,01852 & 0,01852 \\
\hline 10 & 0,0056 & 0,0032 & 0,0064 & 0,0000 & 0,0000 & 0,0000 & 0,01530 & 0,01530 \\
\hline$\sum F_{j}$ & 0,1182 & 0,0513 & 0,0904 & 0,4281 & 0,1877 & 0,1240 & 1,00000 & 1,00000 \\
\hline
\end{tabular}

The hierarchy of experts in transport systems according to the value of the comparative coefficient of competence is shown in Figure 1.

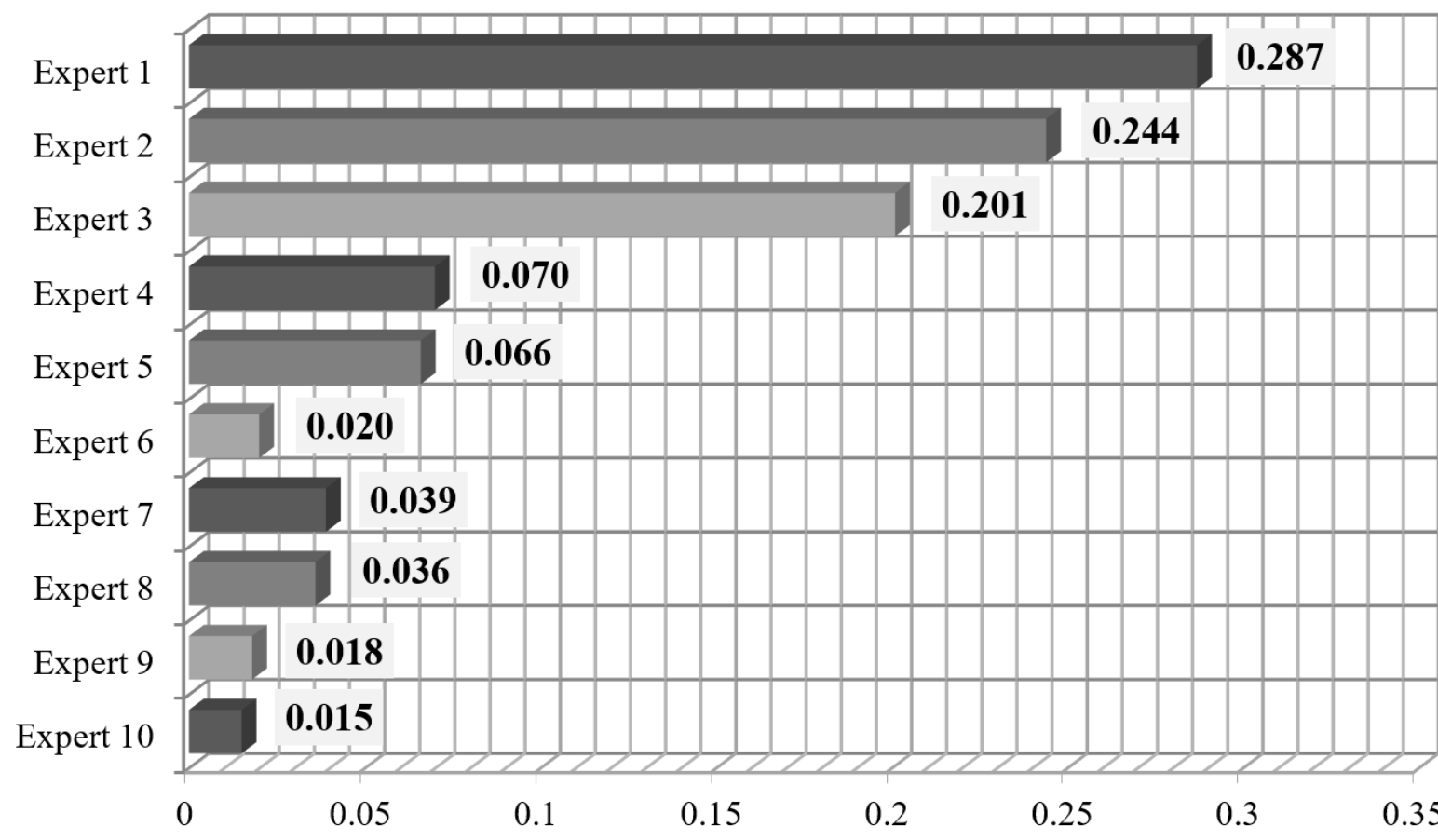

Figure 1. Comparative coefficient of competence $C_{C}$ of experts in transport systems.

The data in Figure 1 show that the highest values of the comparative coefficient of competence are characteristic of experts 1, 2 and 3.

\section{Conclusions}

Determining the comparative level of competence of transport systems experts in the initial group is useful and necessary because it allows the selection and inclusion in the selected group of the most competent specialists, so the qualitative expertise of the most complex cases can be ensured.

The practice of appointing experts with a modest level of competence as experts in transport systems should be removed from the work of decision-makers. 
The elaborated procedure for assessing the comparative level of competence of transport system experts contributes significantly to the creation of the premises for solving a wide range of practical problems, characteristic of the transport industry.

The methodology is easily adaptable to the particularities of the object subject to expertise.

\section{References}

1. Rikov A.S. Sistemniy analiz. Modeli i metodi prinyatia resheniy i poiscovoi optimizatiy. [System Analysis. Models and Methods of Decision Making and Search Engine Optimization]. Moscow, MISiS Publ., 2009, 608 p. (in Russian).

2. Dorofeiuk A.A., Pokrovskaia I.V., Cerneavskii A.L. Ekspertnie metodi analiza i soversenstvovania sistem upravlenia. [Expert Methods of Analysis and Improvement of Control Systems]. In: Automation and telemechanics. 2004, No.10, pp. 172 - 188.

3. Raicu S. Sisteme de transport [Transport systems]. Bucharest, AGIR Publ., 2007, 484 p. (in Romanian).

4. Ambrosi G. Aspects regarding the audit of public transport systems. In: Public administration. 2012, No.76, pp.6772.

5. Velimojin A.V., Gudkov V.A., Mirotin L.B. Osnovi teorii transportnih protessov i sistem. [Fundamentals of the theory of transport processes and systems]. Moscow, Academia Publ., 2015, 224 p. (in Russian).

6. Verescun V.D. Ekspertnie ocenki $v$ proizvodstvenno-transportnih protessah: Voprosi organizațiy, modelirovania $i$ upravlenia. [Expert Evaluations in Production and Transportation Processes: Issues of Organization, Modeling and Management]. In: Fundamental research. 2016, No.4-3, pp. 485-489. (in Romanian).

7. Martemianov I.F., Lazareva T.I. Ekspertnie metodi prinyatia resheniy [Expert Decision Making Methods]. Tambov, TGTU Publ., 2010, 80 p. (in Russian).

8. Velychko O., Gordienco A., Gaber A. Comparative assessment of the competence of experts in the field of higher education by different methods. In: Eastern-European Journal of Enterprise Technologies, 2018, 5/3 (95), pp.2532.

9. Petrichenko G.S. Metodika ocenki kompetentnosti ekspertov [Methods of Assessing the Competence of Experts] In: Science Journal KubGAU, 2015, No.109 (05), pp.1 - 12. (in Russian).

10. Saaty T.L. The Analytic Hierarchy Process: Planning, Priority Setting, Resource Allocation. NY, McGraw-Hill, 1980, $287 \mathrm{p}$.

11. Mariceva P.G. Metodika ocenki kompetentnosti ekspertov [Experts Competence Assessment Methodology] In: Vestnik SGTU, 2018, No.4 (60), pp.29-40. (in Russian).

12. Boico E. Methods of Forming an Expert Assessment of the Criteria of an Information System for Managing Projects and Programs, In: Computer Sciences, 2018, pp.9-11. 